\title{
Rural tourism low carbonization cognitive problems and countermeasures research in Zhejiang \\ - based on the investigation of Big creek village
}

\author{
Hu Jianqiang ${ }^{1,2, a}$, Lou Xiaofeng ${ }^{1, b}$,and Li baiyu ${ }^{1, c}$ \\ 1School of Modern Service, Zhejiang Shuren University, Hangzhou, 310015, China; \\ 2The Research Center of modern service industry of Zhejiang Province, Hangzhou, 310015;

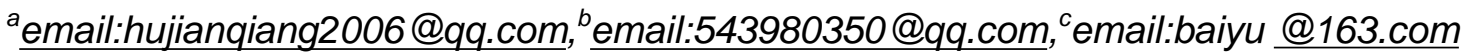

\begin{abstract}
Keywords: Low carbon Tourism; Low carbon economy; Rural tourism; Big creek village
Abstract: Low carbon has become a recognized future development direction of the tourism industry in Zhejiang. Closely linked to this paper, vigorously develop low carbon tourism industry requirements, to Big creek village Anji Zhejiang, for example, through on-the-spot investigation, the problems existed in the village rural tourism low carbon analysis, and put forward the corresponding countermeasures, in order to rural tourism and low-carbon development in our province to find a feasible and with a demonstration of the significance of the road, and for other areas to carry out low carbon tourism experience.
\end{abstract}

\section{Introduction}

Rural tourism is based on the farmers' family management, with the characteristics of rural scenery and rural interest, in order to experience the main content of rural life as the main content of leisure travel . By the end of 2016, the Zhejiang province reported a total development of 3,246 rural tourism villages, 14,840 viable farm units, tourism reception of 183,608,400 visitors, and annual business income reached 1412 billion yuan. On the whole, however, from the current situation in our province, the various links and processes of rural tourism generally exist the problem of high carbon emissions, which directly affects the sustainable and healthy development of rural tourism [1]. Therefore, the low carbonization of rural tourism becomes a difficult problem in theory and practice[2].Based on the basic understanding of the dynamic development of the low carbon tourism education, the author selected Zhejiang province rural tourism model village ----Anji Big creek village as a case, through field research, personal visits the local tourists, tourism enterprises (mainly the farmhouse, the shop) operators, to further study the problem and Countermeasure of low carbon Tourism education.

\section{The Development Situations and Problems of the low carbonization of rural tourism in Big creek village}

Big creek village has won the "Zhejiang Province farmhouse characteristic model village", Anji County socialism new rural construction pacesetter village, Anji best leisure place etc[3].With the Big creek village "Happy farmhouse " developed is getting better, the local village committee come to realize that a good ecological environment is an important prerequisite for sustainable development of "Happy farmhouse ", but also the biggest wealth of Big creek village. Therefore, the village committee to actively explore the construction of "Happy farmhouse ", but it is also faced with many problems in the low carbonization of rural tourism.

Investigation on the operation and development of rural family .

This study used questionnaire and interview method, and the research time was November 2014 and May 2017. Respectively for organic operators and organic visitors designed two kind of questionnaire, survey questionnaires to the farmhouse operator for the first time, 80 valid questionnaires, the second research grant 200 questionnaires to rural tourists, withdraw 197, including 195 valid questionnaires. During the investigation, some operators and tourists were interviewed, and some important information was collected. After the investigation, the questionnaire 
was classified, summarized and counted by Excel, and corresponding analysis was made on the operator's questionnaire and tourist questionnaire.

\section{Investigation of agribusiness operators.}

The survey results showed that $62 \%$ of the farmers in Big creek village were female, while men mainly engaged in some auxiliary work, such as purchasing food and cooking, etc. The employees are mainly local people, mainly in the 40-60 years old, and the education level of employees is generally not high, while those with higher education are less. In the investigation into the degree of its employees, in addition to the $30 \%$ of the operator for the high school culture degree, other operators are junior high school and junior high school the following levels, never accept cultural education accounted for $15 \%$; Operators of agriculturists are engaged in business hours, accounting for $20 \%$ of them over five years, $40 \%$ in three to five years, $30 \%$ in one to three years, and $10 \%$ in less than one year. In terms of tourism professional training, 17 percent of operators have never received training, and 63 percent of the operators have received only superficial training, while only 21 percent have been systematically trained. According to the investigation, $92 \%$ of the farmers in the rural area did not have the phenomenon of prime minister or solicitor during the operation, and said that they increased their knowledge. At the same time, 35 percent of operators believe that the development of farmer-family music has polluted the natural environment. Twenty-two percent of operators believe that village social security is not as safe as before. Fourteen per cent of operators believe that tourists bring bad habits to their farming practices and make neighbour hood relations worse.

\section{Survey of rural tourists.}

According to interviews and questionnaires, Big creek village is mainly from hangzhou and Shanghai, followed by other parts of zhejiang province and jiangsu province, as well as some tourists from places like anhui. Due to its low popularity, poor publicity and poor management, there are basically no tourists from Hong Kong, Macao and Taiwan. Among tourists, $45 \%$ were men and 55\% were women. The occupation of tourists is mainly composed of retirees, teachers and technicians, civil servants, enterprises and managers, among whom the proportion of retirees is the highest, which is $51 \%$. About the purpose of rural leisure tourism (for multiple choice questions), $41 \%$ of visitors to the leisure entertainment, $34 \%$ of visitors is to communicate with friends and family affection, $28 \%$ of visitors come to appreciate the natural scenery, $25 \%$ of visitors to experience rural life, deal with work pressure and rehabilitation training were $8 \%, 70 \%$ of visitors to health rehabilitation, $1 \%$ of visitors to learn, there are $4 \%$ of visitors and other reasons. About the driver of the tourists choose a big creek village farmhouse (for multiple choice questions), survey showed that $83 \%$ think that there is a good natural environment, cheap accounted for $51 \%$, accounted for $11 \%$ of rural culture, unique and comfortable accommodations (42\%), the transportation is convenient $(41 \%)$, the villagers hospitality accounted for $36 \%$. Survey shows that $90 \%$ of visitors certainly big creek village farmhouse, think big creek village mountains and rivers beautiful, a beautiful ecological environment, the road traffic is convenient, location advantage, villagers, simple, kind, the foundation of the development of organic is better.

\section{Problems of the low carbonization of rural tourism}

\section{Lack of enough attention to low carbonization of rural tourism}

Due to lack the enough understanding to the construction of low-carbon tourism for long time, the local development of rural tourism construction is the pursuit of benefits, and there is a certain spontaneity and blindness, protection of the local ecological environment and resources are in a relatively subsidiary position. According to investigation, so far, Big creek village has not organized a low-carbon tourism systemic science education activities, Big creek village rural tourism practitioners' concept of " low carbonization of rural tourism" is not accurate cognition, whether the need to carry out low carbon tourism education also has fudged.

\section{Willingness to carry out the low carbonization of rural tourism is not high}

Based on the spot investigation found of Big creek village, it is not very high for visitors and employees to accept the low carbonization of rural tourism. Most of tourists think that its to enjoy the 
natural scenery, travel beauty, rather than accept a the low carbonization of rural tourism to Big creek village. To accept the low carbonization of rural tourism is bound to affect the tourist mood and the quality of tourism. It has following reason to Big creek village practitioners unwilling to accept a low carbonization of rural tourism: Firstly, their " Happy Farmhouse " has done quite a low-carbon, there is no need to carry out the low carbonization of rural tourism; The second is that the low- carbon or low carbonization of rural tourism reform needs to spend more equipment cost, the financial pressures leading to its unwilling to accept a low carbonization of rural tourism or simply training ; The third is considering a low carbonization of rural tourism of their Happy Farmhouse development can not play the role of economic efficiency, and therefore unwilling to accept low carbonization of rural tourism.

\section{Lack of reasonable planning for low carbonization of rural tourism}

Due to the lack of low carbonization of rural tourism enough attention, Big creek village committee and the relevant departments are not reasonable planning for the development of low carbon Tourism education. In Big creek village, part of the rural tourism, there are still rubbish dumped, low carbon tourism practitioners consciousness, imperfect carbon tourism facilities, tourism product development and irrational phenomena. By visiting the Big creek village committee, the village committee has invested a number of power and money to strengthen the environment management, such as dredging rivers roads, the construction of seven waste transfer station, through various forms of low-carbon environmental advocacy However, due to the " Happy Farmhouse " practitioners cultural level is not high, inadequate attention to environmental protection, low-carbon tourism building did not achieve significant results. The main reason is the lack of low-carbon tourism -related construction personnel on how to conduct a low carbonization of rural tourism system still lacks theoretical understanding.

\section{Countermeasures to solve low carbonization of rural tourism}

The low-carbon tourism is not just a concept, but also a new way of life and travel behavior. It needs tourists, tourism planning and development departments, tourism enterprises, government and tourist -related management department to think and act. According to the development practical of Big creek village "Happy Farmhouse "and the problem of low-carbon tourism, the author puts forward some countermeasures.

\section{Strengthening the importance of low-carbon tourism promotion}

In order to solve the weak low carbon consciousness of tourists and practitioners , the lack of correct understanding of low carbon tourism and other issues, to develop low carbon " Happy Farmhouse " construction of promotional activities, through various forms including promotional pieces, posters, lectures and other forms to enhance " Happy Farmhouse " practitioners to build awareness of the importance of low-carbon tourism, establish a " Happy Farmhouse " building need to support the concept of low carbonization of rural tourism.

\section{Strengthening the construction of low carbonization of rural tourism system}

Carry out the construction of low carbonization of rural tourism, we must solve the problems of the willing of the low carbonization of rural tourism and how to carry out the deficiencies effectively, which requires to establish a long-term mechanism of low carbon tourism education system. The village committee and the relevant department of tourism should be established a low carbon tourism education system which in accordance with Big creek village" Happy Farmhouse "of the actual mechanism, including low carbon tourism education planning, to determine the leader of low carbon tourism education, low carbon tourism education object, the form of low carbon tourism education, the content of low carbon tourism education, put forward the guarantee measures low carbon tourism education and evaluate the achievement of low carbon tourism education, etc. Meanwhile, Big creek village also should strengthen the construction of low carbon tourism education service points, low carbonization of rural tourism service points as the carrier of low carbonization of rural tourism 
should be made clear its composition, function attributes, operational mechanism and management regulations, etc., so as to promote the normal development of carbon tourism education.

\section{Strengthening rural tourism low-carbon tourism star standard construction}

Through the rural tourism low-carbon tourism star standard construction, can greatly improve the Big creek village rural tourism willingness to accept low carbonization of rural tourism practitioners, thereby promoting low carbonization of rural tourism. Rural tourism low-carbon tourism star means rural tourism indicators based on low-carbon assessment of the extent of its division, determining carbon levels. Specific indicators include low carbon content rural tourism level waste disposal, equipment operation and management degree, the extent of low-carbon tourism services, construction of low-carbon tourism products and tourism product is the situation with multiple aspects of educational and other low-carbon. Low-carbon tourism -star standard construction can take environmental protection and " Happy Farmhouse " stakeholders combine to greatly facilitate " Happy Farmhouse " low-carbon tourism practitioners willingness education.

\section{Summary}

To build a low carbonization of rural tourism is an important way to implement a low-carbon economy, is also to put the low carbon tourism concept into practice, and the effective way to guide practice [4]. At present, the low-carbon tourism construction of Big creek village is still in exploring stage, if can from the perspective of the ideological level, to improve the " low carbon concept of Happy Farmhouse " practitioners through education, improve the relevant tourism services, and has the scientific guidance for " Happy Farmhouse " low carbon tourism facilities and product development . It will play an important role to improve the Big creek village " Happy Farmhouse " level of development and the promotion of " Happy Farmhouse " sustainable development; At the same time, the practice of Big creek village of low carbonization of rural tourism will be provide valuable experience and reference to other areas to develop low carbon rural tourism construction, so as to promote the development of low-carbon tourism. And low-carbon tourism will also bring a new era of development for rural tourism in the development of our country, let us concern, think and act get together.

\section{Acknowledgements}

This work is supported by the projects: "Zhejiang rural tourism low carbon demonstration esearch". (15JDNF02YB). Zhejiang province philosophy social sciences research base planning project.

\section{References}

[1] Compiled by zhejiang tourism bureau. Zhejiang tourism development report 2016[M]. Beijing: China tourism publishing house, 2016.

[2] Hu Jianqiang, Jiang Liao, Zheng qinglin, Wan guowei. Model Innovation of Village Resort_Leisure-oriented Service Economy Trends and Management [J]. Ecological Economy, 2010, 3(222):121-123

[3] Zhang jianguo, xue qunhui. Ecological tourism - Taihu source model [M]. Beijing: Peking University press, 2010.

[4] Hu Jianqiang, Shan Wenjun and Li Liang: Carbon Tourism Research Status and Prospects [J]. Zhejiang Shuren University, 2011.11(3):31 - 35 